\title{
Cardiovascular responses to the insertion of naso- gastric tubes during general anaesthesia
}

Eighty female patients free of cardiovascular disease who were having excision of breast lesions were randomly allocated to one of two groups. In the first group a nasogastric tube was inserted blindly during the surgical procedure, while in the second group the tube was inserted under direct laryngoscopy, using Magill forceps. Both groups exhibited a significant increase in systolic blood pressure (SBP) $(p<0.001)$ and heart rate (HR) $(p<0.005)$. These increases declined during the following 3 minutes. Ventricular extrasystoles (more than 5 during the $3 \mathrm{~min}$ following the insertion of the nasogastric tube) occurred only in the group having the nasogastric tube with the aid of laryngoscopy $(p<0.05)$.

Cardiovascular reactions have been reported during laryngoscopy and tracheal intubation, ${ }^{1,2}$ during dental anaesthesia, ${ }^{3}$ oral surgery, ${ }^{4}$ bronchoscopy, ${ }^{5}$ and endoscopy of the gastrointestinal system. ${ }^{6,7}$ These cardiovascular responses may have clinical significance for the patient suffering from severe heart disease. Several studies have identified factors or drugs that may influence these responses ${ }^{8,9}$ and techniques have been proposed to prevent the haemodynamic changes, particularly those associated with laryngoscopy and intubation. ${ }^{10,11}$

\section{Key words}

COMPLiCATIONS: hypertension, tachycardia, arrhythmia; TECHNIQUES: nasogastric tube insertion.

From the Department of Anaesthetics, St. Savas Hospital, Athens, Greece.

Address correspondence to: Dr. A. Fassoulaki, 57-59 Raftopoulou Street, Athens 11744, Greece.
In the present study we investigated the cardiovascular responses during the insertion of a nasogastric tube in anaesthetized patients, comparing two different techniques of insertion.

\section{Methods}

Eighty female patients who were having excision of breast lesions were studied. Consent to participate in the study was obtained. None were suffering from hypertension or heart disease, or receiving any cardiovascular drugs. The ECG on admission to the hospital was normal.

Anaesthesia was induced with fentanyl $5 \mu \mathrm{g} \cdot \mathrm{kg}^{-1}$ and thiopentone $4 \mathrm{mg} \cdot \mathrm{kg}^{-1}$, followed by succinylcholine $1 \mathrm{mg} \cdot \mathrm{kg}^{-1}$ to facilitate tracheal intubation and was maintained with one per cent halothane and $\mathrm{N}_{2} \mathrm{O}$ in $\mathrm{O}_{2}$. Pancuronium was given as required to allow ventilation to be controlled. When the breast mass was removed, and while waiting for the pathology report a $16 \mathrm{~g}$ nasogastric tube, lubricated with lidocaine jelly was inserted through the left nostril. The patients were randomly allocated to one of two groups:

Group I: Blind insertion ( $n=4 l$ ) (Age $43.27 \pm$ 1.31 years). The nasogastric tube, which was at room temperature, was passed through the left nostril with the right hand, while the index and the middle finger of the left hand were inserted into the patient's mouth to guide the tube down the oesophagus and prevent it from coiling in the mouth. The systolic blood pressure (SBP) and heart rate (HR) were recorded before, immediately after and $3 \mathrm{~min}$ following the insertion. SBP was recorded indirectly with a von Recklinghausen oscillotonometer and HR was obtained from the digital readout of a Honeywell monitor. SBP and HR were also recorded every $10 \mathrm{~min}$ intraoperatively. During tube 
passage and during the following $3 \mathrm{~min}$ the ECG (lead II) was recorded on paper. The extrasystoles observed were counted for the $3 \mathrm{~min}$ period following insertion of the nasogastric tube.

Group II: Insertion under laryngoscopy $(n=39)$ (Age $40.89 \pm 1.40$ years). The nasogastric tube was inserted under direct laryngoscopy and using the Magill forceps. SBP, HR and ECG were recorded as in Group I.

All the nasogastric tubes were inserted by the first author with the first attempt and within $30 \mathrm{sec}$, otherwise the patient was eliminated from the study. Arterial blood gas analysis was performed in all patients when the SBP, HR and ECG recordings were completed. The arterial samples were obtained by single puncture from the radial artery and analysed for $\mathrm{PaO}_{2}$ and $\mathrm{PaCO}_{2}$ in an ABL-3 blood gas analyser (Radiometer Copenhagen).

The results were evaluated statistically by Student's $t$ test for paired observations for the parametric data and the Chi-square test with Yate's correction for the non parametric data.

\section{Results}

\section{Blood pressure}

Both groups had a statistically significant increase in SBP $(p<0.001)$ immediately after passage of the nasogastric tube into the stomach. The SBP declined during the following $3 \mathrm{~min}$ but in patients who had laryngoscopy it was still significantly higher $(p<0.05)$ at that time (Table I). The per cent increase of SBP observed after the insertion of the tube under laryngoscopy was 24.9 of the control value and after blind insertion 19.7.

\section{Heart rate}

The nasogastric tube insertion (either blind or under direct laryngoscopy) was associated with a significant increase in heart rate ( $p<0.001$ and $p<0.005$ respectively) (Table II). In both groups there was a 13.5 per cent increase in heart rate. Heart rate had declined $3 \mathrm{~min}$ later and did not differ significantly from the mean values of $H R$ before the insertion of the tube.

\section{Ventricular extrasystoles}

The incidence of ventricular extrasystoles (more than five during the $3 \mathrm{~min}$ period) was significantly higher $(\mathrm{p}<0.05)$ in the group of patients having laryngoscopy. In no case did we observe more than
TABLE I Systolic pressure $-\mathrm{mmHg}$ (mean \pm SEM)

\begin{tabular}{|c|c|c|c|}
\hline & $\begin{array}{l}\text { Before tube } \\
\text { insertion }\end{array}$ & $\begin{array}{l}\text { Immediately } \\
\text { following } \\
\text { insertion }\end{array}$ & $\begin{array}{l}3 \text { minutes } \\
\text { following } \\
\text { inserion }\end{array}$ \\
\hline $\begin{array}{l}\text { Group I } \\
\text { (blind insertion) } \\
n=41\end{array}$ & $122.2 \pm 3.8$ & $\begin{array}{l}146.2 \pm 4.5 \\
p<0.001\end{array}$ & $\begin{array}{l}133.7 \pm 3.9 \\
\text { NS }\end{array}$ \\
\hline $\begin{array}{l}\text { Group II } \\
\text { (laryngoscopy) } \\
\mathbf{n}=39\end{array}$ & $129.9 \pm 3.6$ & $\begin{array}{l}162.2 \pm 5.1 \\
p<0.001\end{array}$ & $\begin{array}{l}137.1 \pm 4.2 \\
p<0.05\end{array}$ \\
\hline
\end{tabular}

NS: no significant difference.

$P$ values - in comparison to pre-insertion data.

five ventricular extrasystoles in patients who had the nasogastric tube inserted blindly.

The mean values $\pm \mathrm{SE}$ of $\mathrm{PaO}_{2}$ were $120.2 \pm$ $6.44 \mathrm{mmHg}$ for Group I and $119.3 \pm 4.9 \mathrm{mmHg}$ for Group II. The $\mathrm{PaCO}_{2}$ was $31.6 \pm 1.1 \mathrm{mmHg}$ and $30.4 \pm 0.9 \mathrm{mmHg}$ respectively.

\section{Discussion}

Regardless of the technique applied, the insertion of the nasogastric tube resulted in a transient increase in SBP and HR. However, the incidence of ventricular extrasystoles was significantly higher in the group of patients having the nasogastric tube inserted under laryngoscopy.

Cardiac dysrhythmias have been reported during oral surgery ${ }^{4}$ and during gastrointestinal endoscopies. ${ }^{6,7}$ These ECG changes are often transient and do not correlate with the presence of heart disease. Arterial hypoxaemia has been incriminated for dysrhythmias observed during upper gastrointestinal endoscopies. ${ }^{12}$ However, in this study ${ }^{12}$ less than 50 per cent of patients received sedation and this may also play a role.

Our patients exhibited no hypoxia or hypercarbia, were anaesthetized and the manoeuvres to pass

TABLE II Heart rate - beats $\min ^{-1}($ mean \pm SEM $)$

\begin{tabular}{llll}
\hline & $a$ & $b$ & $c$ \\
\hline $\begin{array}{l}\text { Group I } \\
\text { (blind insertion) }\end{array}$ & $79.6 \pm 1.8$ & $\begin{array}{l}90.3 \pm 1.9 \\
\mathrm{p}<0.001\end{array}$ & $\begin{array}{l}83.3 \pm 1.9 \\
\mathrm{n}=41\end{array}$ \\
$\begin{array}{l}\text { Group II } \\
\text { (laryngoscopy) }\end{array}$ & $83.6 \pm 2.0$ & $94.8 \pm 3.0$ & $83.6 \pm 2.5$ \\
$\mathbf{n}=39$ & & $\mathrm{p}<0.005$ & $\mathrm{NS}$ \\
\hline
\end{tabular}

NS: no significant difference.

$P$ values - in comparison to pre-insertion dala 
TABLE IIl Frequency of cardiac dysrhythmias during 3-minute observation period

\begin{tabular}{llll}
\hline & $\begin{array}{l}\text { Ventricular } \\
\text { extrasystoles } \\
1-5\end{array}$ & $\begin{array}{l}\text { Ventricular } \\
\text { extrasystoles } \\
>5\end{array}$ & Total \\
\hline $\begin{array}{l}\text { Group I } \\
\mathrm{n}=41\end{array}$ & $8(19.5 \%)$ & 0 & $8(19.5 \%)$ \\
$\begin{array}{l}\text { Group II } \\
\mathrm{n}=39\end{array}$ & $6(15.4 \%)$ & $4(9.7 \%)$ & $10(25.6 \%)$ \\
& NS & $\begin{array}{l}\mathrm{x}^{2} 4.7815 \\
\mathrm{p}<0.05\end{array}$ \\
\hline
\end{tabular}

NS: no significant difference Groups I and II.

the nasogastric tube lasted a shorter time ( $\leqslant 30 \mathrm{sec}$ ) than the time required to perform a gastrointestinal endoscopy. Our patients also were free of surgical stimulus during passage of the tube and the following $3 \mathrm{~min}$ when recordings took place.

It is possible that laryngoscopy influenced the incidence of ventricular extrasystoles. The incidence of dysrhythmias during laryngoscopy varies.' The fact that laryngoscopy lasted about $30 \mathrm{sec}$ might have contributed to the development of extrasystoles.

The hypertensive response after laryngoscopy persisted for $3 \mathrm{~min}$. However, the insertion of the nasogastric tube, or the manoeuvre with the index and middle finger to guide the tube into the oesophagus appear to be responsible for the cardiovascular changes observed in Group I.

We conclude that the insertion of a nasogastric tube in anaesthetized patients should ideally be performed blindly. Laryngoscopy is more likely to provoke dysrhythmias than a blind insertion techique.

\section{References}

1 Katz RL. Bigger Jr JT. Cardiac arthythmias during anesthesia and operation. Anesthesiology 1970; 33: 193-213.

2 Prys-Roberts C, Creene LT, Meloche R, Föex $P$. Studies of anaesthesia in relation to hypertension. II: Haemodynamic consequences of induction and endotracheal intubation. $\mathrm{Br} \mathrm{J}$ Anaesth 1971; 45: 531-46.

3 Thomas VJE, Thomas WJW, Thurlow AC. Cardiac arrhythmia during outpatient dental anaesthesia: the advantages of a controlled ventilation technique. Br J Anaesth 1976; 48: 919-22.
4 Bradshaw EG. Dysrhythmias associated with oral surgery. Anaesthesia 1976; 31: 13-7.

5 Shrader $D L$, Lakshminarayan $S$. The effect of fiberoptic bronchoscopy on cardiac rhythm. Chest 1978; 78: $821-4$.

6 Fujita $R$, Kumura $F$. Arrhythmias and ischemic changes of the heart induced by gastric endoscopic procedures. Am J Gastroenterol 1975; 64: 44-8.

7 McCloy RM, Chiti CC. EKG changes during fiberoptic upper GI endoscopy and colonoscopy. Gastrointest Endosc 1976; 22: 231

8 Cozanitis DA, Nuttila $K$, Merrett JD, Kala $R$. Influence of laryngoscope design on heart rate and rhythm changes during intubation. Can Anaesth Soc J 1984; 31: 155-9.

9 Fassoulaki A, Kaniaris $P$. Does atropine premedication affect the cardiovascular response to laryngoscopy and intubation? Br J Anaesth 1982; 54: 1065-9.

10 Stoelting $R K$. Attenuation blood pressure response to laryngoscopy and tracheal intubation with sodium nitroprusside. Anesth Analg 1979; 58: 116-9.

11 Fassoulaki A, Kaniaris $P$. Intranasal administration of nitroglycerine attenuates the pressures response to laryngoscopy and intubation of the trachea. $\mathrm{Br} \mathbf{J}$ Anaesth 1983; 55: 49-52.

12 Rostykus PS, McDonald GB, Albert PK. Upper intestinal endoscopy induces hypoxemia in patients with obstructive pulmonary disease. Gastroenterology 1980; 78: 488-91.

\section{Résumé}

Quatre-vingt patientes libres de toute atteinte cardiovasculaire devant subir une excision d' une tumeur du sein ont été classés en deux groupes différents d'un façon randomisé. Dans le premier groupe un tube nasogastrique a été inséré à l' aveugle lors de l'opération, et dans le second groupe le tube nasogastrique a été inséré sous laryngoscopie directe avec des pinces Magill. Les deux groupes ant démontré une augmentation significative de la tension artérielle systolique $(p<0.001)$ et de la fréquence cardiaque $(p<0.005)$.

Cette augmentation de la tension artérielle systolique et de la fréquence cardiaque avait tendance à diminuer après trois minutes. Des extrasystoles ventriculaires (plus que cinq extrasystoles ventriculaires dans les trois minutes post insertion du tube nasogastrique) sont survenues uniquement dans le groupe où le tube nasogastrique a été inséré sous laryngoscopie $(p<0.05)$. 